\title{
What should the African health workforce know about disasters? Proposed competencies for strengthening public health disaster risk management education in Africa
}

Olushayo Olu ${ }^{1 *}$ (D), Abdulmumini Usman², Kalula Kalambay ${ }^{3}$, Stella Anyangwe ${ }^{4}$, Kuku Voyi $^{4}$, Christopher Garimoi Orach ${ }^{5}$, Aklilu Azazh ${ }^{6}$, Mala Ali Mapatano ${ }^{7}$, Ngoy Nsenga², Lucien Manga ${ }^{8}$, Solomon Woldetsadik ${ }^{9}$, Francois Nguessan ${ }^{2}$ and Angela Benson ${ }^{10}$

\begin{abstract}
Background: As part of efforts to implement the human resources capacity building component of the African Regional Strategy on Disaster Risk Management (DRM) for the health sector, the African Regional Office of the World Health Organization, in collaboration with selected African public health training institutions, followed a multistage process to develop core competencies and curricula for training the African health workforce in public health DRM. In this article, we describe the methods used to develop the competencies, present the identified competencies and training curricula, and propose recommendations for their integration into the public health education curricula of African member states.
\end{abstract}

Methods: We conducted a pilot research using mixed methods approaches to develop and test the applicability and feasibility of a public health disaster risk management curriculum for training the African health workforce.

Results: We identified 14 core competencies and 45 sub-competencies/training units grouped into six thematic areas: 1) introduction to DRM; 2) operational effectiveness; 3) effective leadership; 4) preparedness and risk reduction; 5) emergency response and 6) post-disaster health system recovery. These were defined as the skills and knowledge that African health care workers should possess to effectively participate in health DRM activities. To suit the needs of various categories of African health care workers, three levels of training courses are proposed: basic, intermediate, and advanced. The pilot test of the basic course among a cohort of public health practitioners in South Africa demonstrated their relevance.

Conclusions: These competencies compare favourably to the findings of other studies that have assessed public health DRM competencies. They could provide a framework for scaling up the capacity development of African healthcare workers in the area of public health DRM; however further validation of the competencies is required through additional pilot courses and follow up of the trainees to demonstrate outcome and impact of the competencies and curriculum.

Keywords: Public health, Disaster risk management, Education, Core competencies, Training curricula, Health workforce, Africa

* Correspondence: oluo@who.int

${ }^{1}$ World Health Organization, PO Box 1324, Kigali, Rwanda

Full list of author information is available at the end of the article 


\section{Background}

The health system framework has been increasingly proposed as the basis for effectively implementing disaster risk management (DRM) within the realm of public health [1-3]. A health system encompasses people and organizations as well as actions; therefore, it is defined as "consisting of all organizations, people and actions whose primary intent is to promote, restore or maintain health" [4]. The health system has six building blocks namely 1) health leadership and governance, 2) health products and technologies, 3) health workforce, 4) financing of health services, 5) management of health information, 6) delivery of health services [4]. These building blocks are interrelated and work in tandem to ensure good health services provision. A resilient health system should have the capacity to effectively prepare for and respond to disasters, preserve key health functions, and recover during and after disaster strikes [5]. Such a system should guarantee good access, coverage, quality, and safety of health services [4], safeguard human life and ensure good health outcomes during and after disasters [5].

The health workforce includes any person who is involved in activities with the ultimate intention to protect and improve health; these include people working in the public and private sectors, formal and informal sectors, and at the community level [4] A strong health workforce is critical for ensuring a resilient health system [5-7], which in turn is a key element of effective public health DRM. The presence of adequate numbers of skilled health care workers (HCWs) is a key determinant of health outcomes during disasters [8]. Available literature points to weak health systems and inadequate numbers of skilled HCWs as key factors that sustained transmission of the 2014-15 Ebola outbreaks in West Africa [9, 10]. Furthermore, a World Health Organization (WHO) report identified the inadequate numbers of HCWs in the Ebola-affected countries, poor training, and a lack of required medical equipment as part of the challenges that hampered early control of the outbreak [11]. Similar challenges have also been observed during other humanitarian crises on the continent, such as the Horn of Africa and Sahel drought crises as well as the ongoing Yellow Fever and Zika virus outbreaks $[12,13]$. These events highlight the need for well-trained and skilled health care workers for public health DRM.

In 2012, the sixty-second session of the WHO Regional Committee for Africa adopted (through resolution AFR/RC62/R1) and is currently implementing a 10-year regional strategy on DRM for the health sector [14]. This strategy aims to improve the capacity of the health sector and to build the institutional capacity of WHO African Region Member States ${ }^{1}$ to manage disasters. Furthermore, it intends to improve individual $\mathrm{HCW}$ competencies for public health DRM, so as to strengthen resilience in the community and health sector. Welltrained and competent health workers were identified as a critical requirement for effective implementation of the strategy, and thus resolution AFR/RC62/R1 includes a clause requesting WHO to "support national capacity building for DRM" [15].

As part of the efforts to implement the human resources capacity building component of the strategy, the WHO African Regional Office (WHO/AFRO) conducted an unpublished desk review of existing emergency public health training programmes in the African Region. ${ }^{2}$ The review showed that there were few available public health emergency courses on the continent, most of which were focused on response to public health disasters especially epidemics and lack critical aspects of public health disaster risk reduction, preparedness and postdisaster health system recovery. Furthermore, the review revealed that the contents of many of the available courses varied and did not include contemporary humanitarian topics, such as the international humanitarian reforms, transformative agenda, legal framework for humanitarian response, and emergency response operations management. This emphasized the need for a comprehensive and harmonized public health DRM training package for African HCWs.

To address this gap, WHO/AFRO, in collaboration with selected African public health training institutions, conducted a multistage pilot study to develop and test comprehensive core competencies and curricula for training the African health workforce in public health DRM. In this article, we present the competencies and training curricula that were identified, describe the stages of their development, and propose recommendations for their completion and integration into the public health education curricula of African public health training institutions. The general objective of the article is to provide information and opportunities that could be used to improve health DRM training in Africa.

\section{Methods}

We conducted a pilot research to develop and test a public health disaster risk management curriculum for training the African health workforce on DRM. We used mixed methods approaches including literature review to better understand the public health disaster risk management training needs and the associated knowledge and skills required by the African health workforce; qualitative research methodology to develop the core competencies and curriculum; knowledge translation and quantitative research methodology to test the applicability and feasibility of the competencies and curriculum. 
We obtained curriculum development terminologies via online searches of Google search engine using the term "curriculum development and terminologies". The search yielded several documents which we reviewed. We selected three of the documents for in-depth review. ${ }^{3}$ The review of the three documents yielded over 30 terminologies out of which we selected four key ones which were relevant to our purpose. These are competency, which was defined as a cluster of related knowledge, skills, and attitudes that enable an individual or organization to perform their core functions well [16]. Learning objectives were defined as a description of what students should know or be able to do at the end of a course that they could not do before the course [17]. We also defined a curriculum as the planned interaction of student with instructional content, materials, resources, and processes for evaluating the attainment of educational objectives [18], and training module was defined as a standardized or selfcontained segment that constitutes an educational course or training programme [19].

We implemented the curriculum development from 2009 to 2013, using a multistage consultative and qualitative process. A team of African emergency public health academicians and practitioners was assembled to: 1) conduct an in-depth review of existing emergency public health training programmes in the African Region; 2) identify knowledge, skills sets, and core competencies required by African HCWs to effectively engage in DRM; 3) develop a generic training curriculum for health DRM that is suited to the region; and 4) agree on the modalities for pilot testing the courses. Participants from the schools of public health of six African universities $^{4}$ as well as emergency public health practitioners from Ministries of Health, the US Centers for Disease Control and Prevention, and the three levels of the WHO participated in the process.

The first stage involved a desk review of the content of available in-service, basic, and specialized training programmes in public health DRM across the African Region as well as agreement on a road map for development of health DRM curricula for Africa and the methodology for identification of the core competencies. The second stage involved the establishment of an upto-date inventory of existing public health DRM training programmes, establishment of partnerships between training institutions and relevant stakeholders to enhance programme quality and continuity, and production of a framework for standardizing training packages with the aim of addressing the continuum of the disaster management cycle at all levels.

In the third stage, we reviewed and listed the knowledge and skills required to effectively implement the regional health DRM strategy through compilation and desk review of the existing literature on health DRM and the associated skill sets and core competencies. At this stage, we organized a consultative meeting to discuss and validate the identified knowledge and skill sets. During the meeting, participating academic institutions presented the health DRM competencies used to develop the public health training curricula of their institutions, which were then compared with the identified list of competencies to ensure that the list was inclusive. A predeveloped template was used to group the knowledge and skills into competencies and sub-competencies, which were then categorized into thematic areas. The learning objectives for each competency were identified and curricula developed for basic, intermediate, and advanced health DRM courses. Finally, all the products of the consultative meeting were endorsed by the experts present who thoroughly reviewed and compared them to what existed in the peer-reviewed literature. At the fourth stage, the final products were sent for peer review to the relevant programmes of $\mathrm{WHO} / \mathrm{AFRO}$, selected ministries of health, and public health training institutions.

In the fifth and final stage, we reviewed the core competencies, learning objectives, and course curricula based on feedback received from the peer review process; we also developed the training units and modules for all core competencies, compiled the work done thus far, and developed a template for writing a guideline/framework for health sector DRM capacity building.

We conducted a pilot test of the basic public health DRM training module at one of the participating training institutions (the University of Pretoria) in conjunction with the South African National Defence Forces (SANDF) and WHO/AFRO in March 2015, to test the applicability and feasibility of the core competencies and curricula. We used quantitative methods (pre- and posttests) to assess the performances of all the participants who attended the pilot course. Similarly, all participants evaluated the relevance of the course and the competencies addressed in it.

\section{Results \\ Core competencies for public health DRM}

We identified 14 core competencies and 45 subcompetencies/training units, grouped into six thematic areas, as the skills and knowledge that African health care workers should possess to be able to effectively engage in public health DRM (Table 1). These six thematic areas are as follows: 1) introduction to DRM; 2) operational effectiveness; 3 ) effective leadership; 4) preparedness and risk reduction; 5) emergency response; 6) post-emergency health system recovery. 
Table 1 Thematic areas and public health emergency core competencies for training African health workers

\begin{tabular}{|c|c|c|}
\hline Thematic area & Core Competency & Training units \\
\hline \multirow[t]{4}{*}{ Introduction to DRM } & $\begin{array}{l}\text { 1. Demonstrate knowledge of public health principles } \\
\text { and practices for Disaster Risk Management }\end{array}$ & $\begin{array}{l}\text { 1.1 Disaster risk management concepts } \\
\text { 1.2 Public health consequences of disasters } \\
\text { 1.3 Context: political, social and economic environment }\end{array}$ \\
\hline & $\begin{array}{l}\text { 2. Demonstrate knowledge of basic epidemiological } \\
\text { methods and data management }\end{array}$ & $\begin{array}{l}\text { 2.1 Basic epidemiology } \\
\text { 2.2 Data analysis and management }\end{array}$ \\
\hline & $\begin{array}{l}\text { 3. Demonstrate the ability to communicate effectively } \\
\text { in DRM }\end{array}$ & $\begin{array}{l}\text { 3.1 Key principles of communication } \\
\text { 3.2 Risk communication } \\
\text { 3.3 Operational communication(any communication } \\
\text { that is not with the media and public) }\end{array}$ \\
\hline & $\begin{array}{l}\text { 4. Demonstrate the knowledge of principles of legal } \\
\text { considerations, human rights and ethics in dealing } \\
\text { with DRM }\end{array}$ & $\begin{array}{l}\text { 4.1 Ethics } \\
4.2 \text { Human rights } \\
4.3 \text { International humanitarian law } \\
4.4 \text { International health regulations }\end{array}$ \\
\hline \multirow[t]{3}{*}{ Operational Effectiveness } & $\begin{array}{l}\text { 5. Demonstrate ability to identify, mobilise and manage } \\
\text { resources }\end{array}$ & 5.1 Resource mobilization \\
\hline & $\begin{array}{l}\text { 6. Demonstrate the ability to apply logistics } \\
\text { management }\end{array}$ & 6.1 Logistics management \\
\hline & $\begin{array}{l}\text { 7. Demonstrate the ability to apply measures of safety } \\
\text { and security }\end{array}$ & $\begin{array}{l}\text { 7.1 Basic security in the field } \\
\text { 7.2 Protection and Family safety }\end{array}$ \\
\hline \multirow[t]{2}{*}{ Effective Leadership } & $\begin{array}{l}\text { 8. Demonstrate effective leadership, teamwork and } \\
\text { management skills required for DRM }\end{array}$ & $\begin{array}{l}\text { 8.1 Principles of leadership and management } \\
\text { 8.2 Leadership } \\
\text { 8.3 Management } \\
\text { 8.4 Coordination }\end{array}$ \\
\hline & $\begin{array}{l}\text { 9. Demonstrate knowledge about the monitoring and } \\
\text { evaluation cycle }\end{array}$ & $\begin{array}{l}\text { 9.1 Key principles } \\
9.2 \text { Monitoring } \\
9.3 \text { Evaluation }\end{array}$ \\
\hline \multirow[t]{3}{*}{ Preparedness and Risk Reduction } & $\begin{array}{l}\text { 10. Demonstrate the ability to conduct capacity } \\
\text { assessments }\end{array}$ & $\begin{array}{l}\text { 10.1 Key principles of capacity assessments } \\
\text { 10.2 Risk assessments } \\
\text { 10.3 Needs assessments }\end{array}$ \\
\hline & $\begin{array}{l}\text { 11. Demonstrate the ability to plan and implement } \\
\text { preventive and mitigation activities }\end{array}$ & $\begin{array}{l}\text { 11.1 Key principles of prevention and mitigation } \\
\text { 11.2 Risk reduction } \\
\text { 11.3 Mitigation }\end{array}$ \\
\hline & $\begin{array}{l}\text { 12. Demonstrate the ability to plan and implement } \\
\text { emergency preparedness at community and health } \\
\text { facility levels }\end{array}$ & $\begin{array}{l}\text { 12.1 Key principles of disaster preparedness } \\
\text { 12.2 Planning } \\
\text { 12.3 Early warning } \\
\text { 12.4 Surge capacity } \\
\text { 12.5 Training } \\
\text { 12.6 Exercise management }\end{array}$ \\
\hline Emergency Response & $\begin{array}{l}\text { 13. Demonstrate ability to apply DRM principles and } \\
\text { practices for the health response to disasters and } \\
\text { public health emergencies }\end{array}$ & $\begin{array}{l}\text { 13.1 Key principles of emergency health response } \\
\text { 13.2 Health assessment } \\
\text { 13.3 Mass casualty management and emergency health } \\
\text { services } \\
\text { 13.4 Incident management } \\
\text { 13.5 Public health programmes in emergencies } \\
\text { 13.6 Planning }\end{array}$ \\
\hline $\begin{array}{l}\text { Post-emergency health system } \\
\text { recovery }\end{array}$ & $\begin{array}{l}\text { 14. Demonstrate ability to plan and implement health } \\
\text { system and population recovery. }\end{array}$ & $\begin{array}{l}\text { 14.1 Key principles of post-disaster health system } \\
\text { recovery } \\
\text { 14.2 Recovery needs assessments } \\
\text { 14.3 Recovery strategy and planning } \\
\text { 14.4 Recovery programme implementation }\end{array}$ \\
\hline
\end{tabular}

1. Introduction to DRM: All health care professionals engaged in health DRM should understand the basic principles of DRM. This thematic area has four core competencies that focus on understanding the principles of public health and disasters, principles of human rights and ethics in disasters, basic epidemiology and data management, and effective communication during disasters. This thematic area is further subdivided into 12 sub-competencies/training units (Table 1). The 14 core competencies, their training units, and learning objectives are outlined in Additional file 1.

2. Operational effectiveness: Acquisition of soft skills in the areas of resource mobilization and 
management, basic logistics management, and application of staff safety and security measures were considered critical elements of a sound public health DRM curriculum; therefore, health care workers should have the necessary skills and knowledge in these areas. This thematic area has four sub-competencies/training units (Table 1).

3. Effective leadership: This thematic area focuses on skills and knowledge associated with leadership, management, coordination, supervision, monitoring, and evaluation of public health DRM programmes and is subdivided into seven sub-competencies/ training units (Table 1).

4. Preparedness and risk reduction: The ability to conduct various types of assessments, plan and implement public health preventive and mitigation measures, and to establish preparedness interventions at the health facility and community levels were identified as critical competencies that health workers should possess to effectively reduce the risk of and to prepare for disasters. This thematic area is subdivided into 12 subcompetencies/training units (Table 1).

5. Emergency response: The ability to apply DRM principles and practices for the health response to disasters was identified as a critical competency that health workers should possess to effectively respond to disasters. This thematic area is subdivided into 6 sub-competencies/training units (Table 1).

6. Post-emergency health system recovery: The ability to apply DRM principles and practices to plan and implement post-emergency health system and population recovery interventions, were identified as critical competencies that health workers should possess to effectively recover from disasters. This thematic area is subdivided into 4 subcompetencies/training units (Table 1).

\section{Training curricula for public health DRM}

Based on the 14 core competencies, we identified three levels of training to suit the needs of various categories of African HCWs, namely, basic, intermediate, and advanced training in public health DRM (Table 2). The delivery and assessment methods for these courses include as modules in undergraduate studies, post-graduate diploma or public health masters courses, or as stand-alone programmes (Table 3). The curricula for basic, intermediate, and advanced training in health DRM are presented in detailed in Additional files 2 and 3).

\section{Piloting the basic public health DRM course}

Twenty-six participants (24 SANDF officers or soldiers and two civilians) attended the pilot basic health DRM training course, which was administered by five facilitators from the University of Pretoria School of Health Systems and Public Health (SHSPH) and WHO/ AFRO. Thirteen lectures and three group work sessions were delivered over the 5-day pilot course. During the group work sessions, trainees used actual examples of disasters such as the Ebola outbreak in Sierra Leone, flooding in northern Namibia, cholera outbreak in Zimbabwe, and the armed conflict in northern Uganda, to simulate and practise the principles of disaster preparedness, risk reduction, response, and recovery. The course covered basic principles of 12 out of the 14 competencies namely: 1) public health principles and practices for DRM; 2) basic epidemiology; 3) risk communication; 4) ethics, human rights, international humanitarian law, and international health regulations; 5) safety and security; 6) leadership and management; 7) monitoring and evaluation; 8) capacity assessment; 9) prevention and mitigation; 10) preparedness; 11) response; and 12) recovery.

The average scores for the pre- and post-tests were 51 . $5 \%$ and $59.2 \%$, respectively. All participants agreed that the course was very appropriate and that their expectations had been met. Nearly all trainees (except one) agreed that the 12 core competencies covered were all relevant to the course and to their public health DRM work. Participants felt that the data management, disaster preparedness, risk reduction, and response sessions were intensive and that more time should be allocated to these in future courses.

\section{Discussion}

The lessons learnt from recent public health events of international concern in Africa have revealed the fragility of the continent's health systems $[10,20]$ and the critical role of HCWs in the public health emergency preparedness, response and recovery framework [21, 22]. These events have demonstrated that competent health workers are needed not only to lead public health services delivery, support planning, supervision, coordination, and evaluation of all aspects of public health disaster management [23-26] but also to prevent the health workforce from being infected or affected by disasters. Significant attention to and investment in the health workforce are therefore critical to ensure resilient health systems that can effectively prepare for, respond to, and recover from disasters [27, 28] Addressing this challenge requires increased numbers as well as improvement in the knowledge and skills of health workers $[27,29,30]$. To the best of our knowledge, there is no comprehensive set of localized competencies to guide these aspects in Africa; therefore, the findings of this study contribute to addressing this perceived gap.

We identified 14 core competencies in six thematic areas, which African HCWs should acquire to be able to 


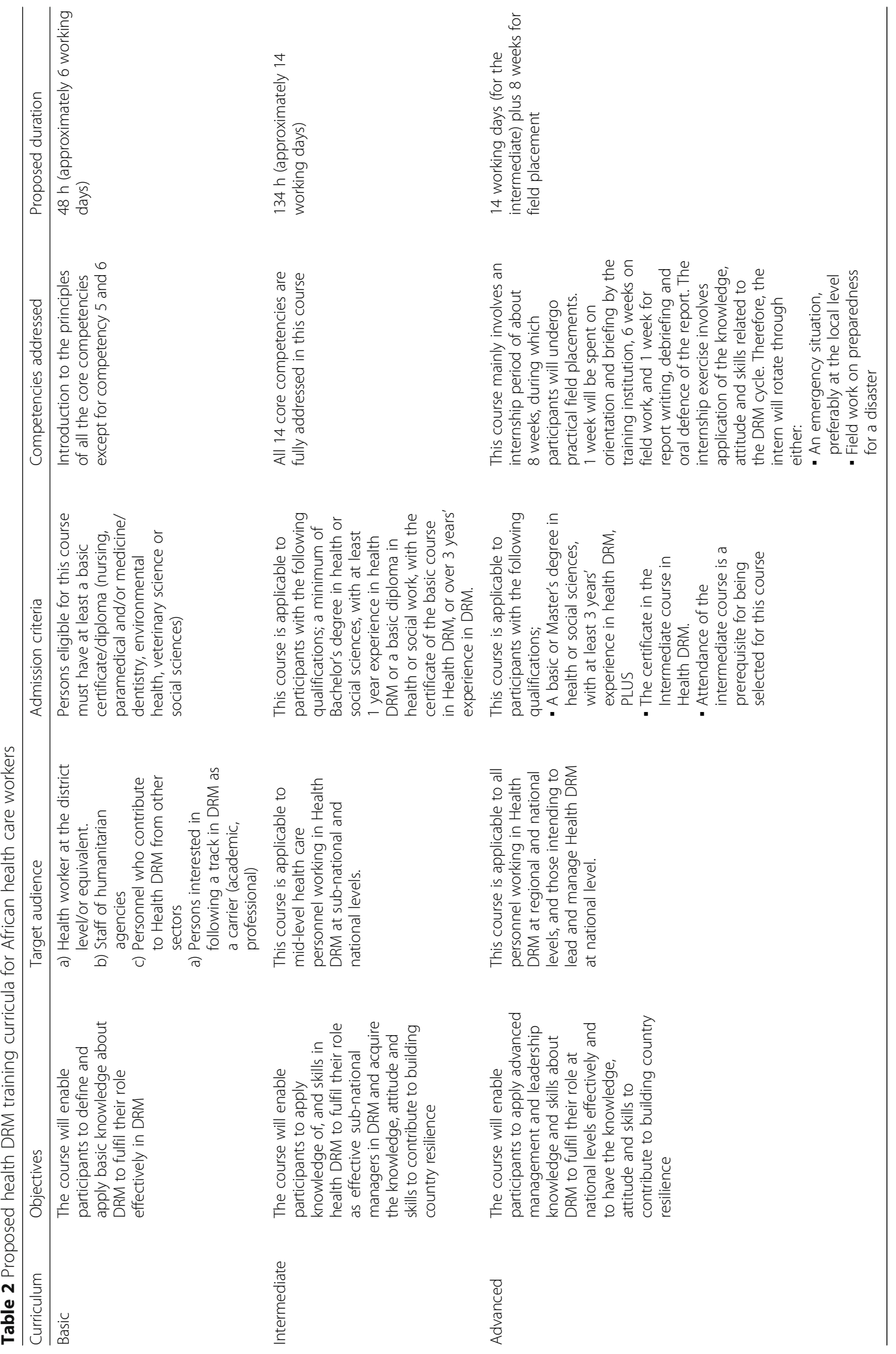


Table 3 Delivery options for basic, intermediate and advanced public health DRM courses in Africa

\begin{tabular}{|c|c|c|c|}
\hline Course & Delivery method & Assessment & Certification \\
\hline \multirow[t]{2}{*}{ Basic course in DRM } & $\begin{array}{l}\text { Incorporated into modules for } \\
\text { undergraduate studies in } \\
\text { medicine, other health } \\
\text { sciences and public health. }\end{array}$ & $\begin{array}{l}\text { Based on university criteria for } \\
\text { assessing the undergraduate } \\
\text { course into which it is } \\
\text { incorporated. }\end{array}$ & $\begin{array}{l}\text { Incorporated into } \\
\text { undergraduate degree award. }\end{array}$ \\
\hline & Stand-alone course & Written examination & $\begin{array}{l}{ }^{a} \text { Certificate of competence of } \\
\text { the participating University or } \\
\text { training institution. }\end{array}$ \\
\hline \multirow[t]{3}{*}{ Intermediate course in DRM } & $\begin{array}{l}\text { Incorporated as a module into } \\
\text { Post-graduate diploma pro- } \\
\text { grammes which are relevant } \\
\text { to DRM. }\end{array}$ & $\begin{array}{l}\text { Based on university criteria for } \\
\text { assessing the Postgraduate } \\
\text { diploma programme into } \\
\text { which it is incorporated. }\end{array}$ & $\begin{array}{l}\text { Incorporated into } \\
\text { Postgraduate diploma }\end{array}$ \\
\hline & $\begin{array}{l}\text { Incorporated as a module into } \\
\text { Master's programmes which } \\
\text { are relevant to DRM, such as } \\
\text { MPH, MSc etc. }\end{array}$ & $\begin{array}{l}\text { Based on university criteria for } \\
\text { assessing the Master's degree } \\
\text { programme into which it is } \\
\text { incorporated }\end{array}$ & $\begin{array}{l}\text { Incorporated into Master's } \\
\text { degree. }\end{array}$ \\
\hline & Stand-alone course & Written examination & $\begin{array}{l}\text { Certificate of competence of } \\
\text { the participating University or } \\
\text { training institution. }\end{array}$ \\
\hline Advanced course in DRM & $\begin{array}{l}\text { As the health DRM track of } \\
\text { health-related Master's degree } \\
\text { programmes, such as MPH or } \\
\text { MSC }\end{array}$ & $\begin{array}{l}\text { The assessment will be } \\
\text { through observation of the } \\
\text { field supervisors ( } 20 \%) \text {, written } \\
\text { field report }(50 \%) \text {, verbal } \\
\text { defence of the report ( } 30 \%) \text {. } \\
\text { Observation by the field } \\
\text { supervisor will be guided by a } \\
\text { questionnaire, and the field } \\
\text { supervisor may be a member } \\
\text { of the oral defence committee. }\end{array}$ & \\
\hline
\end{tabular}

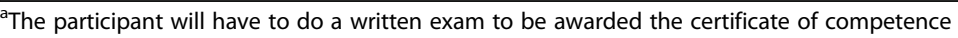

effectively engage in DRM. These competencies could serve as practical guidance for African public health training institutions; ministries of health, education and disaster management; agencies of the United Nations; and national and international nongovernmental organizations, to develop public health DRM educational materials and training programmes for a broad-based category of public health students and workers alike. We propose acquisition of these competencies at three levels, namely, basic, intermediate and advanced. All front-line health workers at district level, junior staff of humanitarian agencies, and personnel from other sectors such as water, sanitation, shelter, and education who contribute to health DRM, should possess and be able to apply basic health DRM skills to manage public health disaster situations at the local level. All mid-level HCWs at provincial and national levels should have and be able to apply intermediate skills and knowledge of all 14 core competencies; HCWs who have direct responsibility for health DRM at national and regional levels should possess and be able to apply advanced health DRM skills and knowledge. We recommend acquisition of the knowledge, skills, and attitudes associated with these competencies through different methodologies. Knowledge could be gained through reading, didactic teaching, projects, assignments and experience sharing while skills and attitudes could be acquired through practical field experience and simulation exercises. These acquisition methodologies should be adapted to suit the local training needs and context.

These competencies, together with the associated curricula and training programmes, are proposed as the minimum requirements for all African HCWs that are involved in public health disaster management. However, we believe that there should be opportunities for African HCWs to attend specialized courses, such as in health disaster risk reduction, mass casualty management, and post-disaster health system recovery, so as to acquire more in-depth knowledge of the core competencies. We identified potential challenges that would need to be addressed to ensure the smooth rollout of these competencies. These include the tendency for courses to focus on didactic teaching methods as opposed to a more practical approach, which might limit field experience among students. Other challenges include the shortage of experienced trainers at the initial stages of rollout of the competencies and curricula, insufficient time allocated for the training programmes, and shortages of funding for public health training institutions to introduce the core competencies into their training programmes. Additional challenges include inadequate financial support for African health workers to participate in training programmes, resistance by African training institutions to introduce the core competencies, and a lack of 
modalities for uniform accreditation of the courses across African countries and training institutions.

Effective implementation and sustainability of these core competencies would require their integration into the broader framework of the Global Health Workforce Alliance, existing public health education, the DRM policies of African member states, and ongoing efforts to strengthen the global emergency health workforce and health security. Therefore, a number of success factors such as high-level political commitment; government involvement and financial investment; good strategic planning for public health DRM workforce education; effective management, leadership, and information; and supervision, monitoring, and evaluation systems are critical $[7,31]$. In this regard, we propose a number of principles that should guide the use of these core competencies to develop public health DRM training programmes and courses.

First, courses should be sustainable, affordable, and accessible and they should be based on training needs that have been identified through training needs assessment. Second, sequencing of and time allocated to the training units and modules should be logical and realistic, to ensure coherence in the course delivery. Third, the principles of right to health, human rights, equity, social justice, and humanitarian assistance should be mainstreamed into the health DRM training courses and programmes. Fourth, the courses should be regularly monitored and evaluated, to ensure that they are of high quality and that they not only meet their objectives and the learning needs of trainees but also the skill needs of African member states. Fifth, in view of the multisectoral nature of DRM, the planning, delivery, and evaluation of training courses should involve experts from other relevant sectors, clusters, organizations and academic institutions as trainers and participants. Lastly, strong advocacy and formation of partnerships between African ministries of health, education, and disaster management, academic institutions, and international and local organizations are required, to ensure adequate funding, development of sustainable funding modalities, availability of the necessary capacities and management systems for public health DRM training programmes in Africa. This would also support consensus building on certification modalities for the courses.

These core competencies should be adapted to the local context, and the resulting training courses should be as practical and field-based as possible. The successful implementation of these core competencies requires strong advocacy at the level of African health, education, and disaster ministries to ensure the availability of appropriate inputs such as funds, human resources, and training materials. We believe that African public health training institutions have the required environment to introduce these competencies in their curricula; these institutions therefore represent one of the greatest assets in scaling up public health DRM capacity building on the continent.

\section{Study limitations}

This study has three main limitations. First, not all members of the team participated in all stages of the consultative process, which were spread over a 3-year period; this could have resulted in memory lapses that might have biased the study findings. Second, the process involved selection of only a small number of African public health training institutions, academicians, and public health DRM practitioners, whose views on health DRM core competencies may not be representative of the views of all African public health experts and training institutions. We mitigated these limitations through peer review of the final outcomes of the consultative process by other African public health academicians and health DRM practitioners in the African Region. Third, the sample size of the cohort of people who participated in piloting of the basic course is small and may not be significant. Furthermore, we were unable to follow up this cohort of people to determine whether they were able to successfully apply the skills acquired during the pilot and if this had an impact on their future public health DRM work thus further pilot testing and validation of all three courses are required.

\section{Conclusions}

Scaling up the capacity development of African HCWs in the areas of public health DRM is critical to ensure resilient health systems. This requires a structured and uniformed approach and guidelines that can be adapted across the continent. The core competencies and subcompetencies identified in this article provide opportunities for addressing this task. These competencies compare favourably to the findings of other studies that have assessed public health DRM competencies [32-35]. The pilot test of the basic course demonstrated the relevance of the core competencies and that their use could result in improving the understanding of public health DRM among participants. However, in view of the small sample size of the pilot course, further validation of these competencies through additional pilot courses and follow up of the trainees is required to establish their outcome and impact on public health DRM. Moving forward, strong advocacy as well as government ownership and support of the public health DRM community, and establishment of African public health DRM training institution networks, are required to scale up public health DRM capacity building in Africa.

To effectively roll out these competencies and curricula across the continent, we put forward four main recommendations. First, WHO/AFRO in collaboration with participating training institutions, should conduct more pilot tests of the basic course and finalize those of the intermediate and advanced courses, develop the learning materials for all three courses, and create awareness about 
these core competencies and curricula among African public health training institutions and ministries of health, education, and disaster management. Second, WHO/ AFRO should liaise with ministries of education and health of its member states to discuss the modalities for their accreditation. Furthermore, the organization should work with these ministries to conduct training of trainers so as to establish a critical mass of trainers who could support initial courses. Third, African public health training institutions should conduct assessments of their emergency public health training programmes, using the above-mentioned competencies as a baseline, to improve their planning and curriculum development for public health DRM training programmes where necessary. Lastly, WHO/AFRO in collaboration with training institutions and ministries of health should develop a monitoring and evaluation framework to ensure the quality of public health DRM training programmes across the African Region [31]. This should include development of relevant process, outcome, and impact indicators that should be used to monitor and evaluate the quality and impact of public health DRM training programmes, trainees, and trainers in the region.

\section{Endnotes}

${ }^{1}$ Algeria, Angola, Benin, Botswana, Burkina Faso, Burundi, Cabo Verde, Cameroon, Central Africa Republic, Chad, Comoros, Republic of Congo, Cote d'Ivoire, Democratic Republic of the Congo, Equatorial Guinea, Eritrea, Ethiopia, Gabon, The Gambia, Ghana, Guinea, Guinea Bissau, Kenya, Lesotho, Liberia, Madagascar, Malawi, Mali, Mauritania, Mauritius, Mozambique, Namibia, Niger, Nigeria, Rwanda, São Tomé and Principe, Senegal, Seychelles, Sierra Leone, South Africa, Republic of South Sudan, Swaziland, Togo, Uganda, United Republic of Tanzania, Zambia, and Zimbabwe.

${ }^{2}$ The reviewed courses include: Health Emergency in Large Populations (HELP); Public Health in Complex Emergencies (PHCE); Field Epidemiology and Laboratory Training Programme (FELTP), Analysing Disrupted Health Systems (ADHS); Public Health Pre-Deployment Course (PHPD), Health Cluster Coordination Training (HCCT).

${ }^{3}$ The selected documents are: 1) UNESCO International Bureau of Education Curriculum Terminology; 2) Columbia University School of Nursing Competencyto-Curriculum Toolkit; 3) British Columbia Ministry of Education Glossary of Curriculum Terms.

${ }^{4} 1$ ) University of Pretoria, South Africa; 2) University of Kinshasa DRC; 3) Addis Ababa University, Ethiopia; 4) Makerere University, Uganda; 5) Maputo University, Mozambique; and 6) Institute of Public Health, Benin.

\section{Additional files}

Additional file 1: Health DRM core competencies, sub-competencies and learning objectives. (DOCX $39 \mathrm{~kb}$ )

Additional file 2: Curriculum for basic, intermediate and advanced training in health DRM. (DOCX $38 \mathrm{~kb})$

Additional file 3: Proposed public health DRM training modules. (DOCX $23 \mathrm{~kb}$ )

\section{Abbreviations}

DRM: Disaster risk management; HCW: Health care worker; SANDF: South African National Defence Forces; WHO/AFRO: African Regional Office of the World Health Organization

\section{Acknowledgements}

The authors thank all African Schools of Public Health that participated in the consultative meetings. We also thank Dr. Isis Plut, Dr. Lynn Atuyambe, Dr. Michael Ghebrehiwet, Ms. Ingrid Obery, Dr. Issa Makumbi, Dr. Godfrey Bwire, Dr. Robert Musoke, Dr. Michael Lukwiya, Mr. Innocent Komakech, and Mr. Jonathan Abrahams for their contributions to the study at various times. The authors alone are responsible for the views expressed in this article, which do not necessarily represent the views, decisions, or policies of the institutions with which they are affiliated.

\section{Funding}

WHO/AFRO, Brazzaville, Republic of the Congo funded the study, coordinated and provided technical assistance (through its staff members who are co-authors) for the study design, data collection, analysis and writing of the manuscript.

\section{Availability of data and materials}

All the data and information used in this article are included as tables or additional files in this published document.

\section{Authors' contributions}

OO, AU, KK, SA, KV, CGO, AA, MAM, NN, LM, SW, FN, and AB participated in the conception and conduction of study, compilation and review of documents, drafting of the manuscript, and made significant inputs into all drafts of the manuscript. All authors read and approved the final draft for publication and agreed to be accountable for all aspects of the work.

\section{Authors' information}

$\mathrm{OO}, \mathrm{AU}, \mathrm{KK}, \mathrm{SA}, \mathrm{NN}, \mathrm{LM}, \mathrm{SW}, \mathrm{FN}$, and $\mathrm{AB}$ were members of the WHO/AFRO Outbreak and Disaster Management (ODM) Programme at various times over several years, and participated in the development of the core competencies. The ODM programme was primarily responsible for development of the public health DRM core competencies. SA, LM, and $A B$ served as ODM programme managers at various times, and AU, KK and FN were Regional Advisers. NN and $0 O$ served as sub-regional focal points for Eastern/Southern Africa and West Africa, respectively, and SW was the country focal point for Uganda. KV, CGO, AA, and MAM are academicians from the Universities of Pretoria, Makerere, Addis Ababa, and Kinshasa, respectively; they were members of the African public health DRM curriculum development team.

\section{Ethics approval and consent to participate}

This study was conducted as part of implementation of the African Regional Strategy for Health DRM. No human subjects were involved in the study, hence ethical approval was not sought. WHO/AFRO approved the publication of the study (WHO e-Pub no: ePub-IP-00067036-EC).

Consent for publication

Not applicable.

Competing interests

The authors declare that they have no competing interests. 


\section{Publisher's Note}

Springer Nature remains neutral with regard to jurisdictional claims in published maps and institutional affiliations.

\section{Author details}

'World Health Organization, PO Box 1324, Kigali, Rwanda. ${ }^{2}$ WHO Regional Office for Africa (AFRO), Brazzaville, Republic of Congo. ${ }^{3}$ International Public Health Disaster Risk Management Consultant, Gatineau, Canada. ${ }^{4}$ School of Health Systems and Public Health, University of Pretoria, Pretoria, South Africa. ${ }^{5}$ School of Public Health, Makerere University, Kampala, Uganda. ${ }^{6}$ Faculty of Medicine, University of Addis Ababa, Addis Ababa, Ethiopia. ${ }^{7}$ School of Public Health, Faculty of Medicine, University of Kinshasa, Kinshasa, Democratic Republic of the Congo. ${ }^{8}$ WHO Country Office, Bamako, Mali. ${ }^{9}$ WHO Emergency Support Hub, Nairobi, Kenya. ${ }^{10}$ International Public Health and Disaster Risk Management Consultant, Monrovia, Liberia.

\section{Received: 8 December 2016 Accepted: 18 March 2018}

Published online: 02 April 2018

\section{References}

1. Bayntun C. A health system approach to all-hazards disaster management: A systematic review. PLoS Curr. 2012; https://doi.org/10.1371/ 50081 cad5861d.

2. Bayntun C. Rockenschaub G. Murray V. Developing a health system approach to disaster management: A qualitative analysis of the core literature to complement the WHO Toolkit for assessing health-system capacity for crisis management. PLoS Curr. 2012; https://doi.org/10.1371/ 5028b6037259a.

3. World Health Assembly Resolution 64.10. 2011. http://apps.who.int/iris/ handle/10665/3566. Accessed 28 Sept 2016.

4. Everybody's business. Strengthening health systems to improve health outcomes; WHO's framework for action. Geneva: World Health Organization. 2007. http://www.who.int/healthsystems/strategy/everybodys_business.pdf. Accessed 28 Sept 2016.

5. Kruk ME, Myers M, Varpilah ST, Dahn BT. What is a resilient health system? Lessons from Ebola. Lancet. 2015;385(9980):1910-2. https://doi.org/10.1016/ S0140-6736(15)60755-3.

6. Chen L, Evans T, Anand S, Boufford Jl, Brown H, Chowdhury M, et al. Human resources for health: overcoming the crisis. Lancet. 2004:364(9449):1984-90.

7. Crisp N, Gawanas B, Sharp I. Training the health workforce: scaling up, saving lives. Lancet. 2008;371(9613):689-91. https://doi.org/10.1016/S01406736(08)60309-8

8. Health worker Ebola infections in Guinea, Liberia and Sierra Leone - a preliminary report. World Health Organization. 2015. http://apps.who.int/iris/ bitstream/10665/171823/1/WHO_EVD_SDS_REPORT_2015.1_eng.pdf?ua= 1\&ua=1. Accessed 21 Nov 2016

9. Regmi K, Gilbert R, Thunhurst C. How can health systems be strengthened to control and prevent an Ebola outbreak? A narrative review. Infect Ecol Epidemiol. 2015;5:28877. https://doi.org/10.3402/iee.v5.28877.

10. Chan M. Ebola virus disease in West Africa - no early end to the outbreak N Engl J Med. 2014;371(13):1183-4. https://doi.org/10.1056/NEJMp1409859.

11. Global health emergency workforce report by the Director-General. World Health Organization. 2015. http://apps.who.int/gb/ebwha/pdf_files/WHA68/ A68_27-en.pdf?ua=1. Accessed 21 Nov 2016.

12. Green A. Yellow fever continues to spread in Angola. Lancet. 2016; 387(10037):2493. https://doi.org/10.1016/S0140-6736(16)30835-2.

13. Nishino K, Yactayo S, Garcia E, Aramburu GJ, Manuel E, Costa A, et al. Yellow fever urban outbreak in Angola and the risk of extension. Wkly Epidemiol Rec. 2016;91(14):186-92.

14. Olu O, Usman A, Manga L, Anyangwe S, Kalambay K, Nsenga N, et al. Strengthening health disaster risk management in Africa: multi-sectoral and people-centred approaches are required in the post-Hyogo framework of action era. BMC Public Health. 2016;16:691. https://doi.org/10.1186/s12889016-3390-5

15. African Regional Committee Resolution AFR/RC62/6. 2012. http://apps.who. int/iris/bitstream/10665/80074/1/AFR-RC62-R1-e.pdf. Accessed 28 Sept 2016.

16. Definition of competency. http://www.businessdictionary.com/definition/ competence.html. Accessed 28 Sept 2016.

17. Definition of learning objectives. http://www.businessdictionary.com/ definition/learning-objective.html. Accessed 26 Mar 2018.
18. Definition of curricula. Retrieved from https://en.wikipedia.org/wiki/ Curriculum. Accessed 26 Mar 2018.

19. Definition of training module. http://www.businessdictionary.com/ definition/module.html. Accessed 28 Sept 2016.

20. Kieny MP, Dovlo D. Beyond Ebola: a new agenda for resilient health systems. Lancet. 2015;385(9963):91-2. https://doi.org/10.1016/S01406736(14)62479-X.

21. Editorial. No health workforce, no global health security. Lancet. 2016; 387(10033):2063. https://doi.org/10.1016/50140-6736(16)30598-0.

22. Sidibé M, Campbell J. Reversing a global health workforce crisis. Bull World Health Organ. 2015;93(1):3. https://doi.org/10.2471/BLT.14.151209.

23. Van Devanter N, Leviss P, Abramson D, Howard JM, Honoré PA. Emergency response and public health in hurricane Katrina: what does it mean to be a public health emergency responder? J Public Health Manag Pract. 2010; 16(6):E16-25. https://doi.org/10.1097/PHH.0b013e3181d8bbb2.

24. Savage C, Kub J. Public health and nursing: a natural partnership. Int J Environ Res Public Health. 2009;6(11):2843-8. https://doi.org/10.3390/ ijerph6112843.

25. Rowney $\mathrm{R}$, Barton $\mathrm{G}$. The role of public health nursing in emergency preparedness and response. Nurs Clin North Am. 2005;40(3):499-509.

26. Lee LA, Collings A. Sydney hailstorms: the health role in the recovery process. Med J Aust. 2000;173(11-12):579-82.

27. Editorial. Human resources for health-investing in action. Lancet. 2016; 387(10028):1591. https://doi.org/10.1016/S0140-6736(16)30246-X.

28. Heymann DL, Chen L, Takemi K, Fidler DP, Tappero JW, Thomas MJ, et al. Global health security: the wider lessons from the West Africa Ebola virus disease epidemic. Lancet. 2015;385(9980):1884-901. https://doi.org/10.1016/ S0140-6736(15)60858-3.

29. Dieleman M, Gerretsen B, Van der Wilt G. Human resource management interventions to improve health workers' performance in low and middle income countries: a realist review. Health Res Policy Syst. 2009;7:7. https:// doi.org/10.1186/1478-4505-7-7.

30. Walsh L, Altman BA, King RV, Strauss-Riggs K. Enhancing the translation of disaster health competencies into practice. Disaster Med Public Health Prep. 2014:8(1):70-8. https://doi.org/10.1017/dmp.2014.7.

31. Scaling up, saving lives. Taskforce for scaling up education and training for health workers. 2008. http://www.who.int/workforcealliance/documents/ Global_Health_FINAL_REPORT.pdf?ua=1. Accessed 8 Nov 2016.

32. Walsh L, Subbarao I, Gebbie K, Schor KW, Lyznicki J, Strauss-Riggs K, et al. Core competencies for disaster medicine and public health. Disaster Med Public Health Prep. 2012;6(1):44-52. https://doi.org/10.1001/dmp.2012.4.

33. Loke AY, Fung OW. Nurses' competencies in disaster nursing: implications for curriculum development and public health. Int J Environ Res Public Health. 2014;11(3):3289-303. https://doi.org/10.3390/ijerph1 10303289.

34. Daily E, Padjen P, Birnbaum MA. Review of competencies developed for disaster healthcare providers: limitations of current processes and applicability. Prehosp Disaster Med. 2010;25(5):387-95.

35. Hsu EB, Thomas TL, Bass EB, Whyne D, Kelen GD, Green GB. Healthcare worker competencies for disaster training. BMC Med Educ. 2006;6:19. https://doi.org/10.1186/1472-6920-6-19.

\section{Submit your next manuscript to BioMed Central and we will help you at every step:}

- We accept pre-submission inquiries

- Our selector tool helps you to find the most relevant journal

- We provide round the clock customer support

- Convenient online submission

- Thorough peer review

- Inclusion in PubMed and all major indexing services

- Maximum visibility for your research

Submit your manuscript at www.biomedcentral.com/submit
Biomed Central 